\title{
The role of management accounting systems in sustainable and development strategies.
}

\author{
Hassan NASSEREDDINE \\ The Bucharest University of Economic Studies, Bucharest, Romania \\ And \\ Lebanese International University, Beirut, Lebanon \\ Hassan.Nassereddine@gmail.com \\ Amar SAYED AHMAD \\ The Bucharest University of Economic Studies, Bucharest, Romania \\ Amar_s_a@hotmail.com
}

\begin{abstract}
The cycle of corporate measures in line with consideration of apprehensions related to supportable progress and communal and environmental accountability broadens the constraint of routine measurement to take into justification social and environmental gauges. The role of management accounting, historically orientated toward the dimension of economic and financial performance, is consequently questioned in its capacity to evolve towards an integration of these standards into the dimension, management and performance reporting fashions. Environmental control Accounting may be understood as an extension of outmoded management accounting (Anthony 1988, Simons 1995) toward environmental control (Boiral 2007, Renaud 2009). Conversely, several pieces of research tend to indicate that, some distance from integration, we'd rather witness phenomena of loose coupling among monetary, environmental and social performance systems. Management accounting could then be refocused on management and reporting of economic and economic overall performance, even as different functions of the enterprise might be in charge of the social and environmental dimensions of overall performance. This can be seen as an instance of Brunsson's (1989) thesis on organizational hypocrisy. The purpose of this paper is to look at the position of management accounting structures in sustainable and development techniques. Specifically, it is a concern of interrogating closely the speculation of a decoupling that would bring about the focusing of control accounting systems on the sole scope of financial and economic measures and reporting. The study will use a survey method of quantitative research to examine the impacts of the inclusion of environmental and social dimensions to the management accounting basic functions. It will engage workers of entities working in Lebanon. A survey will examine management accountants' perceptions about the Environmental Management Accounting. The results will show the possibilities of actions of the environmental management accounting and the arbitration between financial priorities, environmental and social issues and will propose different configurations of environmental management accounting.
\end{abstract}

Keywords: Environmental Management Accounting, Social and environmental responsibility, Management Accounting, Reporting, Arbitration.

\section{Introduction}

This article aims to understand the innovation process of environmental management accounting (EMA).

Environmental management accounting is at the crossroads of 3 worlds. First, traditional accounting, primarily based on neoclassical roots, considers sustainability issues 
usually in terms of externalities, marketplace screw-ups, charge alerts and economic incentives, however, has been gradual to understand sustainable development as a matter of accounting. Secondly, the purpose of research "environmental management accounting" is considered thru the prism of studies of innovation, particularly as a management innovation. Management accounting improvements are understood as "new" or cutting-edge sorts of accounting and control accounting structures (Zawawi and Hoque, 2010). Environmental uncertainties, current global demanding situations, consisting of climate exchange, shortage of herbal resources, have an effect on these innovations in control accounting. Third, EMA refers to sustainable development. Alternative progress indicators regularly show that the state of environmental degradation and social inequalities are reaching new heights every year.

We can think that the immense challenges of sustainable development and the practice of accounting are very distant, yet it is urgent to understand the "creation of systems and methods by which the governance of development sustainable development can be achieved "(Porritt, 2007). To gain a better understanding of the processes that turn management accounting innovations, from ideas to practice, this article aims to answer the following research questions:

- How could the tools of environmental accounting affect the traditional perimeter of management accounting and how could these tools affect behaviours in organizations and the way of defining strategies?

- How could the environmental management accounting tools be adopted and what are the consequences for the adopting organization, and how can an accounting innovation create the conflict of authenticity at the time of adoption?

- How are management accounting tools reflected in organizations' practices?

From a literature review we will present the limits of the possibilities of actions of the environmental management accounting, and from a selection of environmental accounting tools how their integration into the management accounting of an organization would lead to an expansion of its scope: what is measured, the actors that are taken into account by the tools, the time horizon that is retained, and the increase in the uncertainty in which decisions are made, and we will ask the question of the arbitration between financial and environmental priorities. If the tools of environmental accounting actually make it possible to integrate the environment in the decision-making processes, what happens when the requirements of profitability and respect of the environment are mutually incompatible?

The study uses a survey method of quantitative research to examine the impacts of the inclusion of environmental and social dimensions to the management accounting basic functions.

As such, we will propose different configurations of EMA.

\section{Literature review}

\section{The brakes and drivers for sustainable policies adoption}

In their report on the brakes and drivers for the adoption of sustainable behaviour by transnational corporations, Gray and Bebbington (1994) clearly outline the limits of actions for companies that want to implement sustainable development policies. 
The question is not how organizations can become sustainable, but how they can shape behaviour internally to reduce their impact on the environment and to measure the gap that separates them from the sustainable conduct of their activities.

The tools traditionally associated with management accounting (cost calculation, budgets, dashboards, investment evaluation) focus only on the area under the control of the organization and its legal scope. The organization is a system that consumes external resources, in order to produce goods and services whose value must be greater than the cost of the resources mobilized to put them on the market. The organization is a system whose purpose is to model, understand and control the internal mechanisms of resource transformation and value creation (vision of the organization). Its goal is to create value by maximizing the difference between the costs the resources it assumes and the selling price of the goods and services it sells (management philosophy). Only the financial elements for which the company is legally responsible or non-financial indicators that may ultimately result in a financial impact for the company (such as customer satisfaction indicators) are taken into account.

The technical substrate of the tools consists of a system for collecting financial and non-financial data, rules for allocating a cost to resources, and then distributing the cost of these resources on cost objects. The objectives are to measure the value created by the sales of products and services, to anticipate financial performance through non-financial indicators such as the customer satisfaction rate. The organization relies on how these tools establish a causal relationship between the resources consumed and its ability to match them to create value beyond the cost of those resources. The recipients of the information produced are internal to the company for the purposes of control, diagnostic or interactive purposes.

Recent works by Meyssonnier and Pourtier (2012) show that contractual solutions such as franchising, licensing contracts, and certain supply contracts, allow companies to extend the control arm beyond the perimeter of the traditional management accounting model presented above. For example, should a large hotel group report only on the turnover of the hotels it owns, or should it add the turnover of the hotels operated by its franchisees, and in what way? Given the reflections expressed by Meyssonnier and Pourtier (2012), these evolutions also underline the possibility of a company to exert an influence on the environmental policy of its suppliers, distributors and customers. But are contractual provisions associated with the classic model and tools of management accounting enough to define the field of environmental management accounting and to implement sustainable policies?

\section{Environmental management accounting conceptual framework}

For Gray (1987), social and environmental accounting is a process of communicating the social and environmental effects of an organization's economic actions to certain groups in society in general. According to Gray et al (2000), it offers another way of accounting for significant economic entities. It has the potential to expose the tensions created by the joint pursuit of profit and social and environmental objectives. It is from this perspective of accountability for changing representations and practices that Robert Gray continues his project of defining a conceptual framework for social and environmental accounting (Gray, 
1992, 2000, 2002). However, this act of accountability also has internal effects, since it requires companies to build an infrastructure to collect information about their environmental and social impacts. According to Gray (2000), they can expect benefits in terms of:

- Increasing the amount of information used for decision making;

- More precise cost calculation for the products or services produced or rendered by the company;

- Identification of the areas of social responsibility of the company;

- Identification of development opportunities in new markets;

- Consolidation of the company's legitimacy and improvement of its image.

For Antheaume and Christophe (2006), the term environmental accounting refers to the tools that allow On one hand to complete what the general accounting counts by taking into account the physical flows and costs that the company causes to others because of its actions, and on the other hand, to extend the categories of actors to whom the company makes the accounts.

As for Burrit's, Hahn \& Schaltegger's (2002) approach, it aims more specifically at defining the field of EMA.

Table 1. Environmental accounting as a subset of an accounting information system

\begin{tabular}{|l|l|l|}
\hline Accounting & Monetary measures & Physical measures \\
\hline Non-environmental aspects & $\begin{array}{l}\text { Internal usage } \\
\text { External usage }\end{array}$ & $\begin{array}{l}\text { Internal usage } \\
\text { External usage }\end{array}$ \\
\hline Environmental aspects & $\begin{array}{l}\text { Internal usage } \\
\text { External usage }\end{array}$ & $\begin{array}{l}\text { Internal usage } \\
\text { External usage }\end{array}$ \\
\hline
\end{tabular}

Source: (Burrit et al., 2002)

Once the field of environmental accounting has been defined, Burrit et al. identified EMA (Table 2), which they define as a system for generating, analyzing and using financial and non-financial information, to optimize the ecological and economic performance of a company, to ensure its sustainability.

EMA is defined by its main users and its purpose, which is to provide relevant and useful information to the managers of an organization, distinctly from external stakeholders, to help them perform their duties.

Table 2. The fields of environmental management accounting

\begin{tabular}{|c|c|c|}
\hline Environmental accounting & Monetary measures & Physical measures \\
\hline Internal EMA & $\begin{array}{l}\text { Internal Monetary Environmental } \\
\text { Management Accounting (MENA) }\end{array}$ & $\begin{array}{l}\text { Internal Physical Environmental } \\
\text { Management Accounting (PEMA) }\end{array}$ \\
\hline \multirow{2}{*}{$\begin{array}{l}\text { External } \\
\text { Accounting }\end{array}$} & $\begin{array}{l}\text { External Monetary Environmental } \\
\text { Accounting And reporting (EMEA) }\end{array}$ & $\begin{array}{l}\text { External Physical Environmental } \\
\text { Accounting And reporting (EPEA) }\end{array}$ \\
\hline & $\begin{array}{l}\text { Monetary environmental } \\
\text { accounting and reporting. }\end{array}$ & $\begin{array}{l}\text { Physical environmental regulatory } \\
\text { accounting and reporting. }\end{array}$ \\
\hline
\end{tabular}

DOI: 10.2478/picbe-2019-0028, pp. 313-325, ISSN 2558-9652| Proceedings of the $13^{\text {th }}$ International Conference on Business Excellence 2019 
In the context of EMA, based on parameters such as past or future orientation, the routinely or ad-hoc production of data, consideration of the long term or the short term periods, the authors identify what the implemented tools might look like (Table 3). A tool such as the Balanced Scorecard, which mobilizes both physical and monetary indicators, cannot, however, be part of this highly segmented typology, which also does not offer a vision of the specificities of an environmental management accounting that goes beyond simple classification.

Table 3. An overview of management accounting tools

\begin{tabular}{|c|c|c|c|c|c|}
\hline & \multicolumn{4}{|c|}{ Environmental management accounting } \\
\hline & & \multicolumn{2}{|l|}{ Monetary } & \multicolumn{2}{|l|}{ Physical } \\
\hline & & Short-Term Focus & Long-Term Focus & Short-Term Focus & Long-Term Focus \\
\hline \multirow[b]{2}{*}{ Past Orien } & $\begin{array}{l}\text { Routinely } \\
\text { information }\end{array}$ & $\begin{array}{l}\text { Environmental cos } \\
\text { accounting }\end{array}$ & $\begin{array}{l}\text { Trend analysis of } \\
\text { environmentally } \\
\text { induced costs, } \\
\text { revenues, etc. }\end{array}$ & $\begin{array}{l}\text { Material and energ } \\
\text { flow accounting }\end{array}$ & \begin{tabular}{|l|} 
Environmental \\
capital impact \\
accounting
\end{tabular} \\
\hline & $\begin{array}{l}\text { Ad } \quad \text { hoc } \\
\text { information }\end{array}$ & $\begin{array}{l}\text { Ex post assessment } \\
\text { of } \quad \text { relevan } \\
\text { environmental } \\
\text { costing decisions }\end{array}$ & $\begin{array}{l}\text { Post investment } \\
\text { insessment of } \\
\text { individual projects }\end{array}$ & $\begin{array}{l}\text { Ex } \\
\text { of } \quad \text { short assessmen } \\
\text { environmental } \\
\text { impacts }\end{array}$ & \begin{tabular}{|l} 
Post investment \\
assessment \\
physical \\
environmental \\
investment \\
appraisal
\end{tabular} \\
\hline \multirow{2}{*}{\begin{tabular}{|l} 
Future \\
Oriented
\end{tabular}} & $\begin{array}{l}\text { Routinely } \\
\text { information }\end{array}$ & $\begin{array}{l}\text { Monetary } \\
\text { environmental } \\
\text { operational } \\
\text { budgeting (flows) } \\
\text { Monetary } \\
\text { environmental } \\
\text { apital budgeting } \\
\text { (stocks) }\end{array}$ & $\mid \begin{array}{ll}\text { Environmental long } \\
\text { term } & \text { financial } \\
\text { planning } & \\
& \\
& \end{array}$ & $\begin{array}{l}\text { Material and energ } \\
\text { flow accounting }\end{array}$ & \begin{tabular}{|l|} 
Environmental \\
capital impact \\
accounting
\end{tabular} \\
\hline & \begin{tabular}{|l} 
Ad hoc \\
information
\end{tabular} & $\begin{array}{l}\text { Relevant } \\
\text { environmental } \\
\text { costing (e.g. specia } \\
\text { orders, product mix } \\
\text { with production } \\
\text { constraint) }\end{array}$ & \begin{tabular}{|l|} 
Monetary \\
environmental \\
project investment \\
xlappraisal. \\
$\mathrm{n}$ Environmental life \\
cycle budgeting and \\
target pricing. \\
\end{tabular} & $\begin{array}{l}\text { Relevant } \\
\text { environmental } \\
\text { timpacts }\end{array}$ & $\begin{array}{l}\text { Physical } \\
\text { environmental } \\
\text { investment } \\
\text { appraisal. } \\
\text { Life cycle analysis } \\
\text { of specific projects. }\end{array}$ \\
\hline \multicolumn{6}{|c|}{$\begin{array}{l}\text { Source: (Burrit et al., 2002, p43) } \\
\text { Schaltegger (2011) distinguishes between market and non-market processes. The } \\
\text { irst act in the context of the contractual and market relations that the organization has with } \\
\text { certain stakeholders (employees, suppliers, customers, etc.). The others act out of contractual } \\
\text { and commercial relations, via the company's exposure to media coverage, solicitations from } \\
\text { various interest groups, legislative process etc. If traditional management accounting focuses }\end{array}$} \\
\hline
\end{tabular}


on the phenomena and processes of the market, then the specificity of EMA would be to look at phenomena and processes outside the market to understand: how non-market phenomena could have economic consequences on a company, via market and non-market processes; and how market phenomena could have economic consequences on a company, via nonmarket processes.

Here we find a definition of environmental control similar to that defined by Acquier (2007) when he discusses the management of free figures as part of the implementation of a sustainable development strategy.

In the definition of EMA proposed by Schaltegger (2011), the organization is presented as a system that consumes external resources in the context of market and nonmarket relations, in order to produce goods and services that must meet the needs of its customers, by creating short-term and long-term value, via the market, under the constraint of not causing off-market effects that could affect the long-term economic viability of the business.

Environmental management accounting tools must, therefore, help to model, understand and control non-market phenomena and mechanisms, understand the chains of causality that lead to the creation or destruction of value, evaluate how the company contribute to it, and to modify them accordingly. These tools broaden managers' perspectives beyond the financial elements that the company is legally responsible for.

The organization relies on how these tools establish a cause-and-effect relationship between the resources consumed by the enterprise and its ability to match them to create or destroy value through non-market processes. The recipients of the information produced are internal to the company for control, diagnostic or interactive purposes.

Unlike traditional management accounting, the accounting information system is not an important data provider. The same is true for data collection systems for external environmental communication with respect to environmental management accounting.

\section{The Arbitration between financial and environmental priorities}

Many researchers in economics or management have raised the question of the cost of setting up environmental policies for companies, the impact on their profitability, the negative or positive link between ecological performance and financial performance.

Salzmann et al. (2005), in their review of the literature devoted to the study of the links between environmental and financial performance, concludes that the link between the two is unclear. Depending on contextual elements (sector of activity, indicators selected for the study, time horizon, etc.) the link can appear as positive or negative. On the other hand, even if it is positive, it is difficult to identify the meaning of causality: are the most profitable companies the ones that can afford to have a good environmental performance, or are their good financial performance it results, in particular, from an exemplary environmental policy?

In many cases, more environmentally friendly design or production decisions will conflict with profitability requirements or social objectives (eg maintaining jobs at a site). When no environmental accounting tool is put in place to bring up such a contradiction, no management discussion can take place, but what happens if an environmental accounting tool shows a need for arbitration? The question is posed, but not resolved, by Wynder (2010) who proposes, in a case study, an evaluation exercise of three managers on the basis of the 
indicators of a balanced scorecard that includes an environmental dimension. In terms of balanced scorecard proposals that include such an environmental dimension, they have a normative character, concerning the type of indicators that should be chosen, but not the way to arbitrate. There is a debate on how to build such dashboards. Meysonnier and RasolofoDistler (2008) summarize this by stating that one can either introduce environmental elements into chains of causality that then translate into an improvement or a decrease in environmental performance, or introduce the fifth axis in the balanced scorecard and challenge the hierarchical side of the axes (learning, process, customers, finance, ...) at the service of the financial finality. Finally, a fully independent balanced scorecard can be built solely for the purpose of external communication, decoupled from the financial communication and the link that might possibly be established with financial communication.

\section{Methodology}

The aim of the study was to test the implementation of EMA in the companies studied. The study used a survey method of quantitative research to examine the impacts of the inclusion of environmental and social dimensions to the management accounting basic functions.

Quantitative research was adopted since the aim was to understand the attitudes, awareness and actions of respondents towards EMA in their organizations, and to allow for greater objectivity in obtaining the results. The sample decided on in the quantitative study is a long way extra than qualitative studies and this complements the generalization of the results (Rugg \& Petre, 2006). With quantitative research, the consequences received from are assured as they can be compared with comparable studies across time (Kruger, 2003). the principle disadvantage of quantitative studies is the generation of superficial records due to the fact its miles difficult to get the real meaning of a problem by using looking at numbers received from quantitative studies, and due to the fact that solutions might be the closest fit for that respondent.

The study adopted a random sampling approach to select 100 participants from different Lebanese companies with more than 50 employees belonging to environmentallysensitive industries, that is industries which tend to act in ways that are non or less pollutant and harmful to the environment. Environmental sensitive industries would, therefore, be generalized as those industries that do not impact negatively on the environment.

The decision was taken to conduct the quantitative research through questionnaires since respondents perceived questionnaires as simple and since this way gives us the ability to reach a large number of respondents very quickly and cost-effectively (Lancaster, 2005). However, a questionnaire is also disadvantageous in that, one, it may have a low response rate, a situation whereby some of the respondents may not be willing to fill the questionnaires. Secondly, questionnaires may bring along uncontentious and dishonest replies where the target population may give wrong responses regarding the topic questions. Finally, the questionnaires lack personalization hence hidden agendas that may be expressed through facial gestures and expressions may not be simple to realize.

The questionnaires were personally administered to each respondent in the sample and participants were briefed about the background of the research and its main objectives: 
to examine the impacts of the inclusion of environmental and social dimensions to the management accounting basic functions.

The data, obtained through the questionnaire was then exported to SPSS program to perform descriptive statistics to analyze the variables. Descriptive statistics present the results by means of percentages, frequencies and measures of central tendency or dispersion.

\section{Results and discussions}

\section{Background of Respondents}

Respondents' background was categorized into the job position held and length of service.

The results are presented in the following tables:

Table 4. Shows the job positions of respondents in the survey.

\begin{tabular}{|l|l|l|}
\hline & Item & Frequency \\
\hline $\mathbf{1}$ & Production Manager & 60 \\
\hline $\mathbf{2}$ & Environmental Manager & 18 \\
\hline $\mathbf{3}$ & Health and Safety Manager & 12 \\
\hline $\mathbf{4}$ & Other & 10 \\
\hline
\end{tabular}

Source: Authors' own research results Above half $(60 \%)$ of the respondents were production managers. This was followed by respondents who are Environmental Managers (18\%) and Health and Safety Managers $(12 \%)$. Only $10 \%$ of the respondents were not occupying production or environmental related positions in their organizations.

Table 5. Shows the Length of Service at the organization

\begin{tabular}{|l|l|l|}
\hline & Item & Frequency \\
\hline $\mathbf{1}$ & Less than one year & 10 \\
\hline $\mathbf{2}$ & One to Two years & 14 \\
\hline $\mathbf{3}$ & Two to Five years & 20 \\
\hline $\mathbf{4}$ & Five years and above & 56 \\
\hline
\end{tabular}

Source: Authors' own research results Above half (56\%) of the respondents have served their organization for a minimum of five years or more. The result showed that most respondents have long experience and knowledge of their organization's operations.

\section{Environmental management accounting implementation}

The second section of the questionnaire covered the different aspects of EMA implementation and investigated the inclusion of monetary and physical information in the organization's records.

The results are presented below:

\section{Part A:}

Table 6. Are environmental objectives linked with the company's corporate goals?

\begin{tabular}{|l|l|l|}
\hline & Item & Frequency \\
\hline $\mathbf{1}$ & Yes & 64 \\
\hline $\mathbf{2}$ & No & 36 \\
\hline
\end{tabular}

Source: Authors' own research results

The majority (64\%) of the respondents believe that environmental objectives are linked with the company's corporate goals. 
Table 7. Are environmental issues considered during the development of new products?

\begin{tabular}{|l|l|l|}
\hline & Item & Frequency \\
\hline 1 & Yes & 70 \\
\hline 2 & No & 30 \\
\hline
\end{tabular}

Source: Authors' own research results

The majority (70\%) of the respondents believe that environmental issues are considered during the development of new products, which assures the result obtained from the last question.

Table 8. Does your organization generate and record physical environmental information in respect of the following inputs and outputs? (Select more than one if applicable)

\begin{tabular}{|l|l|l|}
\hline & Item & Frequency \\
\hline $\mathbf{1}$ & Raw materials & 35 \\
\hline $\mathbf{2}$ & Water used & 32 \\
\hline $\mathbf{3}$ & Energy use & 30 \\
\hline $\mathbf{5}$ & Solid waste & 24 \\
\hline $\mathbf{6}$ & Hazardous waste & 18 \\
\hline $\mathbf{7}$ & Air emissions & 15 \\
\hline
\end{tabular}

Source: Authors' own research results

As is clearly evident from questions 1 and 2 above for those respondents who link environmental objectives with the company's corporate goals and with the development of new products, high percentages of organizations generate relevant reports on physical environmental inputs and outputs.

Table 9. Does your organization generate and record monetary environmental information

in respect of the following inputs and outputs? (Select more than one if applicable)

\begin{tabular}{|l|l|l|}
\hline & Item & Frequency \\
\hline $\mathbf{1}$ & Natural resources & 33 \\
\hline $\mathbf{2}$ & Energy & 33 \\
\hline $\mathbf{3}$ & Waste and emissions & 25 \\
\hline $\mathbf{4}$ & Preventive environmental activities & 15 \\
\hline $\mathbf{5}$ & Environmental research and development projects & 12 \\
\hline
\end{tabular}

Source: Authors' own research results

A large percentage of the respondents generate and record general monetary environmental information related to natural resources (66\%), Energy (66\%) and Waste and Emission (50\%). This is logical as almost every manufacturing concern controls the costs of the products manufactured through detailed costing reports. The percentage of respondents believing that their organizations generate monetary information related to Preventive environmental activities and Environmental research and development projects is relatively low.

Table 10. Are the following routinely information generated by the company?

\begin{tabular}{|l|l|l|}
\hline & Item & Frequency \\
\hline $\mathbf{1}$ & Environmental cost accounting & 33 \\
\hline $\mathbf{2}$ & Monetary environmental operational budgeting & 27 \\
\hline $\mathbf{3}$ & $\begin{array}{l}\text { Environmentally induced capital expenditure and } \\
\text { revenues }\end{array}$ & 20 \\
\hline $\mathbf{4}$ & Environmental long-term financial planning & 18 \\
\hline
\end{tabular}

DOI: 10.2478/picbe-2019-0028, pp. 313-325, ISSN 2558-9652| Proceedings of the $13^{\text {th }}$ International Conference on Business Excellence 2019 


\begin{tabular}{|l|l|l|}
\hline $\mathbf{5}$ & Material and energy flow accounting & 35 \\
\hline $\mathbf{6}$ & Physical environmental budgeting & 30 \\
\hline $\mathbf{7}$ & Environmental capital impact accounting & 17 \\
\hline $\mathbf{8}$ & Long-term physical environmental planning & 15 \\
\hline
\end{tabular}

A large percentage of the respondents generate routinely monetary and physical environmental information:

The answers indicate that a large percentage of organizations generate past-oriented and short term environmental information (66\% for monetary and $70 \%$ for physical).

In second place companies generate future-oriented and short term environmental information (54\% for monetary and $60 \%$ for physical).

The percentage of companies generating long term routinely information is below $50 \%$ for physical and monetary information:

$40 \%$ and $34 \%$ respectively for past-oriented, long term information, and $36 \%$ and $30 \%$ respectively for future-oriented, long term information.

Table 11. Are the following ad hoc information generated by the company?

\begin{tabular}{|l|l|l|}
\hline & Item & Frequency \\
\hline $\mathbf{1}$ & Ex-post assessment of relevant environmental costing decisions & 26 \\
\hline $\mathbf{2}$ & Relevant environmental costing & 24 \\
\hline $\mathbf{3}$ & Environmental life cycle costing & 20 \\
\hline $\mathbf{4}$ & Monetary environmental project investment appraisal & 15 \\
\hline $\mathbf{5}$ & Ex-post assessment of short-term environmental impacts & 28 \\
\hline $\mathbf{6}$ & Relevant environmental impacts physical environmental investment 15 & 24 \\
\hline $\mathbf{7}$ & $\begin{array}{l}\text { Post-investment assessment of } \\
\text { appraisal }\end{array}$ & 15 \\
\hline $\mathbf{8}$ & Physical environmental investment appraisal & 15 \\
\hline
\end{tabular}

Source: Authors' own research results

The answers to this question were relatively similar to the answers obtained from the last question which indicates that most of the companies generate in the first place pastoriented and short term ad-hoc monetary and physical environmental information. The percentage of organizations generating long term ad-hoc information is below $50 \%$ for past and future-oriented information, either for monetary or physical types.

Part B:

Table 12.An answer to topic questions

\begin{tabular}{|l|l|l|l|l|l|l|}
\hline & Question & $\begin{array}{l}\text { Strongl } \\
\mathbf{y} \\
\text { Disagre } \\
\mathbf{e}\end{array}$ & $\begin{array}{l}\text { Disagre } \\
\mathbf{e}\end{array}$ & Neutral & Agree & $\begin{array}{l}\text { Strongly } \\
\text { Agree }\end{array}$ \\
\hline $\mathbf{1}$ & $\begin{array}{l}\text { management accounting systems should focus } \\
\text { on the sole scope of economic and financial } \\
\text { measures and reporting }\end{array}$ & 20 & 12 & 12 & 40 & 16 \\
\hline $\mathbf{2}$ & $\begin{array}{l}\text { arbitration between financial priorities, } \\
\text { environmental and social issues is possible } \\
\text { within management accounting systems }\end{array}$ & 14 & 24 & 16 & 40 & 6 \\
\hline
\end{tabular}




\begin{tabular}{|l|l|l|l|l|l|l|}
\hline $\mathbf{3}$ & $\begin{array}{l}\text { EMA can add financial value to the business } \\
\text { operation (i.e. financial gain is greater than } \\
\text { financial costs). }\end{array}$ & 14 & 20 & 14 & 40 & 12 \\
\hline $\mathbf{4}$ & $\begin{array}{l}\text { The company could integrate easily } \\
\text { environmental management system with the } \\
\text { management accounting system. }\end{array}$ & 16 & 26 & 20 & 42 & 12 \\
\hline $\mathbf{5}$ & $\begin{array}{l}\text { EMA can improve the quality of external } \\
\text { reporting such as Corporate Social } \\
\text { Responsibility Reports. }\end{array}$ & 4 & 16 & 16 & 44 & 20 \\
\hline $\mathbf{6}$ & $\begin{array}{l}\text { EMA can ease or eliminate environmental- } \\
\text { related pressure from the general public in the } \\
\text { company. }\end{array}$ & 0 & 10 & 20 & 56 & 14 \\
\hline $\mathbf{7}$ & $\begin{array}{l}\text { EMA can reduce environmental-related costs, } \\
\text { such as waste process costs, legal fees and } \\
\text { compliance costs. }\end{array}$ & 2 & 12 & 16 & 52 & 18 \\
\hline $\mathbf{8}$ & $\begin{array}{l}\text { EMA can help in achieving a cleaner production } \\
\text { and reducing the environmental impact of } \\
\text { business operations. }\end{array}$ & 0 & 10 & 16 & 54 & 20 \\
\hline $\mathbf{9}$ & $\begin{array}{l}\text { EMA is becoming a necessity for due external } \\
\text { pressures. }\end{array}$ & 4 & 14 & 22 & 50 & 10 \\
\hline $\mathbf{1 0}$ & $\begin{array}{l}\text { EMA can improve the organization's image and } \\
\text { reputation. }\end{array}$ & 0 & 8 & 16 & 50 & 26 \\
\hline
\end{tabular}

The answers to these questions revealed that a relatively high percentage of the respondents believe that companies should focus on the scope of economic and financial measures and reporting (32\%) and that the arbitration between financial priorities, environmental and social issues are still difficult within management accounting systems (38\%). Almost the same percentage of respondents (42\%) believe that the integration of EMA systems within accounting systems is not easy. secondly, more than half of respondents (52\%) believe that EMA can add financial value to the business operation and that its financial benefit is greater than its financial costs. Furthermore, the majority of respondents believe that EMA can improve the quality of external reporting (66\%), ease or eliminate environmental-related pressure $(70 \%)$, and improve the organization's image and reputation (76\%). Finally, approximately $68 \%$ of respondents believe that EMA can help in achieving a cleaner production and reducing the environmental impact of business operations and almost the same percentage believe that EMA can reduce environmental-related costs, such as waste process costs, legal fees and compliance costs.

\section{Conclusion}

This study examines the impacts of the inclusion of environmental and social dimensions to the management accounting basic functions and the possibilities of arbitration between financial and environmental priorities.

It was interesting to note that the study revealed that environmental sustainability may still be regarded as an unknown concept to many but many organizations are practising its principles. The study has shown that the majority of respondents are aware that 
environmental management matters and their related costs are important to the organization.

The study revealed that most companies included in the sample generate EMA reports. These reports were divided into PEMA and MEMA and were basically past-oriented and for a short period of time. On analysis, organizations generated slightly more PEMA reports than MEMA reports in their EMA reporting.

PICBE | 324

It was found that high regulatory and economic pressures have encouraged business managers to prepare for EMA development, especially in relation to material and energy flows and efficiency.

In addition, the findings of the study revealed that although there is an awareness of the importance of environmental issues among these companies, and although with the inclusion of environmental and social dimensions to the management accounting basic functions, financial implications and reporting are always the major focus of the companies. Companies are willing to implement EMA related tools as long as the consequences for them are financially beneficial.

Finally, this study showed that EMA and through the gathering of both physical and monetary environmental information impacts of operations, has a crucial role to play in promoting the sustainable development of organizations, and in reducing the environmental impacts of the organization by bringing all the hidden environmental costs to the attention of the role players.

\section{References}

Acquier, A. (2007). Les modèles de pilotage du développement durable. Doctorat en Sciences de Gestion, Paris : Ecole des Mines de Paris.

Anthony, R.N. (1988). The management control function. Boston: Harvard business school press.

Burritt, R., Hahn, T. and Schaltegger, S. (2002), "Towards a comprehensive framework for environmental management accounting”, Australian Accounting Review, Vol. 12, No. 2, pp. 39-50.

Gray R.H, Owen, D.L., Maunders, K.T. (1987). Corporate Social Reporting: Accounting and accountability. Hemel Hempstead: Prentice Hall.

Gray, R., Bebbington J. (1994). Sustainable Development and Accounting: A Research Investigation by the United Nations Conference on Trade and Sustainable Development, University of Dundee, Scotland.

Gray, R.H. (1992). Accounting and Environmentalism. Accounting, Organisations and Society 17(5): 399-425.

Gray, R.H. (2000). Current Developments and Trends in Social and Environmental Auditing, Reporting \& Attestation. International Journal of Auditing 4 (3): 247-268.

Gray, R.H. (2002). The social accounting project and Accounting Organizations and Society. Accounting, Organizations and Society 27: 687-708

Kruger, D. J. (2003). Integrating quantitative and qualitative methods in community research. The Community Psychologist, 36, 18-19.

Meyssonnier, F. et Rasolofo, D. (2008). Le contrôle de gestion entre responsabilité globale et performance économique. Comptabilité - Contrôle - Audit, tome 14, volume 2. 
Meyssonnier, F., Pourtier F. (2012). Contrôle du perimetre et perimetre du contrôle, Journées d'Etude en Contrôle de Gestion de Nantes.

Porritt, J. (2007) "Foreword”, In J. Unerman, J. Bebbington, \& B. O'Dwyer (Eds.), Sustainability accounting and accountability. London, New York: Routledge.

Rugg, G. \& Petre, M. (2006). A gentle guide to research methods, New York, USA, Open University Press.

PICBE | 325

Salzmann, O., Ionescu-somers, A., Steger, U. (2005). The Business Case for Corporate Sustainability: European Management Journal, Volume 23, Issue 1, pp. 27-36.

Schaltegger, S., Gibassier, D., Zvezdov, D. (2011). Environmental Management Accounting, A bibliometric Literature Review. University of Lüneburg, Working paper.

Simons, R. (1995). Control in an age of empowerment. Havard Business Review, March-April: 80-88.

Unerman, J., Bebbington, J., \& O’Dwyer, B. (2007) “Introduction to sustainability accounting and accountability", Sustainability accounting and accountability. London, New York: Routledge.

Wynder, M. (2010), Chemical: Evaluating performance based on the balanced scorecard. Journal of Accounting Education, Ed 28, pp. 221-236.

Zawawi, N. H. M., \& Hoque, Z. (2010) "Research in management accounting innovations: An overview of its recent development", Qualitative Research in Accounting \& Management, vol. 7, issue 4, p. 505-568. 